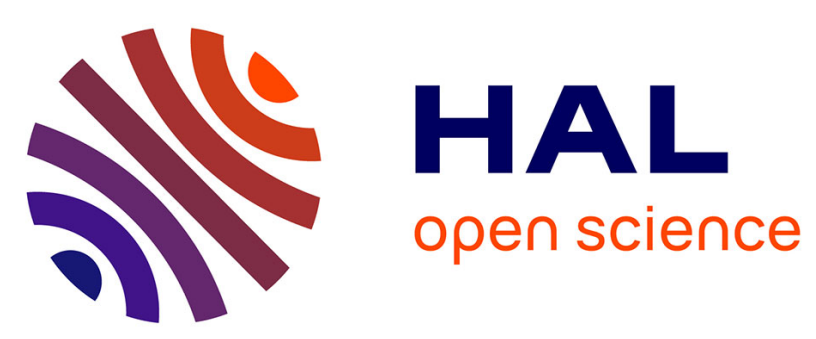

\title{
A Mössbauer spectrometry study of iron in hepatic and splenic tissues. Preliminary results
}

\author{
C. Kellershohn, C. Audebert, D. Fortier, J.N. Rimbert, Cédric Hubert
}

\section{To cite this version:}

C. Kellershohn, C. Audebert, D. Fortier, J.N. Rimbert, Cédric Hubert. A Mössbauer spectrometry study of iron in hepatic and splenic tissues. Preliminary results. Revue de Physique Appliquée, 1980, 15 (6), pp.1175-1178. 10.1051/rphysap:019800015060117500 . jpa-00244838

\section{HAL Id: jpa-00244838 https://hal.science/jpa-00244838}

Submitted on 1 Jan 1980

HAL is a multi-disciplinary open access archive for the deposit and dissemination of scientific research documents, whether they are published or not. The documents may come from teaching and research institutions in France or abroad, or from public or private research centers.
L'archive ouverte pluridisciplinaire HAL, est destinée au dépôt et à la diffusion de documents scientifiques de niveau recherche, publiés ou non, émanant des établissements d'enseignement et de recherche français ou étrangers, des laboratoires publics ou privés. 


\title{
A Mössbauer spectrometry study of iron in hepatic and splenic tissues. Preliminary results
}

\author{
C. Kellershohn, C. Audebert, D. Fortier, J. N. Rimbert and C. Hubert \\ Laboratoire de Biophysique, Faculté de Médecine Necker-Enfants Malades, Paris, France
}

(Reçu le 20 novembre 1979, révisé le 21 mars 1980, accepté le 31 mars 1980)

\begin{abstract}
Résumé. - La ferritine, protéine de réserve du fer chez les mammifères, est constituée d'un noyau d'hydroxyde de fer entouré d'une couche protéique. Plusieurs études effectuées par spectrométrie Mössbauer sur les molécules de ferritine extraites de rate de cheval montrent que le noyau de fer présente des propriétés superparamagnétiques et que l'effet Zeeman nucléaire, caractéristique d'un ordre magnétique, apparaît au-dessous de températures 40$30 \mathrm{~K}$. Parmi les organes et les tissus, ce sont le foie et la rate qui présentent le contenu en fer le plus élevé, principalement sous forme de ferritine et d'hémosidérine. Dans le présent travail, des spectres Mössbauer d'échantillons lyophilisés de rate et de foie de cheval, de bœuf et de veau ont été réalisés aux températures du laboratoire, de l'azote et de l'hélium liquide. Conformément aux travaux antérieurs on trouve sur les échantillons lyophilisés de rate de cheval, que les spectres à 4,2 $\mathrm{K}$ sont essentiellement caractérisés par un effet Zeeman du noyau de fer. Par contre on observe dans les spectres d'échantillons de foie lyophilisés de cheval, de bœuf et de veau, à une température aussi basse que celle de l'hélium liquide, un doublet $\mathrm{Fe}^{3+}$, représentant une fraction importante du spectre Mössbauer en sus du sextuplet Zeeman.
\end{abstract}

\begin{abstract}
Ferritin, mammalian iron reserve protein, is made of a ferric hydroxide core enclosed in a protein shell. Several Mössbauer spectrometry studies have been carried out on ferritin molecules extracted from horse spleen. They demonstrate the existence of superparamagnetic properties in the iron core and the coming out of a nuclear Zeeman effect, characteristic of a magnetic order, below 40-30 K temperatures. Among the organs and tissues of the boby, the liver and spleen usually rank highest in iron content, mainly as ferritin and hemosiderin. In the present work, Mössbauer spectra of lyophylized samples of liver and spleen from horse, beef and calf have been recorded at room, liquid nitrogen and liquid helium temperature. In accordance with the previous works we find for the lyophylized horse spleen samples, the spectra at $4.2 \mathrm{~K}$ are mainly characterized by a Zeeman effect of the iron nucleus. On the other hand, in lyophylized samples of horse liver, even at liquid helium temperature, a doublet corresponding to $\mathrm{Fe}^{3+}$ is observed, in addition to the Zeeman sextuplet, representing an important fraction of the Mössbauer spectrum.
\end{abstract}

1. Introduction. - It is in the bone marrow and red blood cells that the major concentration of iron is found in, the adult human, $60-75 \%$ of the total, principally in the form of circulating hemoglobin. But among the organs and tissues of the body, the liver and spleen usually rank highest in iron content, containing $7-15 \%$ of the total iron in the human body [1]. Table I is taken from Zuyderhoudt et al. [2] to show the distribution of iron in normal human liver according to its biochemical composition. The major part is found in the form of ferritin and a lesser amount as hemosiderin. These two constitute about $90 \%$ of the iron in hepatic tissue, the remainder being distributed among various heme enzymes. They form the storage iron of mammalian species and play an essential role in their physiology.

Ferritin is a protein with a molecular weight of about 700.000 which contains up to $30 \%$ if its weight as iron, in the form of an inorganic ferric hydroxidephosphate polymer consisting of an average of 2500 atoms of iron enclosed in a protein shell [3].
Table I. - Analysis of iron compounds in biopsy specimens of normal human liver in $\mu \mathrm{g} / \mathrm{g} d r y$ weight.

$\begin{array}{cccc}\begin{array}{c}\text { Total liver } \\ \text { iron }\end{array} & \begin{array}{c}\text { Ferritin } \\ \text { iron }\end{array} & \begin{array}{c}\text { Haem } \\ \text { iron }\end{array} & \begin{array}{c}\text { Non-ferritin } \\ \text { depot } \\ \text { iron } \\ \text { (hemosiderin) }\end{array} \\ 730 & - & - & -\end{array}$

When saturated the core contains about 4500 atoms of iron and has an outer diameter of $80 \AA$, while the outer diameter of the protein shell is of the order of $120 \AA$. The term hemosiderin is applied to granules containing a variable quantity of iron (representing $29 \pm 8 \%$ of their dry weight) and which, contrary to ferritin, is insoluble.

Table II is from a study in the rat by Drysdale and Ramsay [4] showing,in this animalat least, the quantity of ferritin is much greater than that of hemosiderin in the liver, the reverse being true for the spleen. It also 
Table II. - Quantity of iron present in the form of ferritin and hemosiderin in the liver and spleen of normal adult male rats, in $\mu \mathrm{g} / \mathrm{g}$ dry weight.

\begin{tabular}{lccc}
\multicolumn{1}{c}{ Organ } & $\begin{array}{c}\text { Number of } \\
\text { animals }\end{array}$ & Ferritin & Hemosiderin \\
- & - & - & - \\
Liver & 46 & $336 \pm 40$ & $96 \pm 24$ \\
Spleen & 46 & $548 \pm 140$ & $1456 \pm 400$
\end{tabular}

shows that in the rat the total quantity of storage iron is about 5 times greater in the spleen than in the liver.

Mössbauer spectrometry has been used to study both of these components by Blaise et al. [5], Boas and Window [6], Fischbach et al. [7], Webb and Gray [8], Williams et al. [9] and Bauminger et al. [10]. The principal finding of these studies was a drastic change in the spectra at temperatures around $35-40 \mathrm{~K}$. Above this temperature the spectra consist of a $\mathrm{Fe}^{3+}$ doublet. Below this, a magnetic hyperfine splitting appears, and, at a sufficiently low temperature, the spectrum consists of the six characteristic lines of the nuclear Zeeman effect in iron. This result has been interpreted by supposing that the small particles of the iron of ferritin and of hemosiderin are superparamagnetic and display antiferromagnetic order of the atoms of iron at sufficiently low temperatures. The spectra, at the temperature of liquid helium, can be analyzed in terms of the continuous distribution of the hyperfine magnetic field, which then permits determination of the distribution of the dimensions of the iron particles in a sample [9].

These investigations with Mössbauer spectrometry have been carried out on ferritin or hemosiderin, extracted by various chemical procedures, sometimes after enrichment with ${ }^{57} \mathrm{Fe}$, and principaily on ferritin of horse spleen. Most of research on ferritin has been done with molecules extracted from horse spleen, an organ which in this animal is particularly rich in storage iron. It seemed to us that it would be interesting to avoid the chemical extraction step for ferritin and hemosiderin and to employ the Mössbauer technique for direct measurements on the hepatic and splenic tissues themselves, after a simple conventional lyophylization.

2. Material and methods. - Different samples of liver and spleen from horse, beef and calf were studied. After washing in cold running water for 24 hours, the samples of the organs were immersed in physiological saline in a proportion of $1 / 3$ tissue and $2 / 3$ saline. The mixture was ground in a blender. The mixture thus obtained was sufficiently thick to be placed in a thin layer in a balloon and immersed in liquid nitrogen. It was then lyophylized at $-90^{\circ} \mathrm{C}$ under vacuum of 0.05 torr. Some spectra were obtained on samples of Bovine Liver purchased by the National Bureau of Standards as biological matrix standard reference materials for trace element determination [11].
The content of iron in the different samples of lyophylized tissue, measured by activation analysis, was between 250 and $17.500 \mu \mathrm{g} / \mathrm{g}$ in the spleen and between 150 and $800 \mu \mathrm{g} / \mathrm{g}$ in the liver. For each of the three types of animal it was higher in the splenic than in the hepatic tissues (Table II). In both the liver and spleen the highest levels of iron were found in the horse.

- The spectra were recorded by means of a constant acceleration device, using a source of $50 \mathrm{mCi}$ of ${ }^{57} \mathrm{Co}$ in rhodium and a Harwell proportional counter. The absorber of $8 \mathrm{~mm}$ thickness and $18 \mathrm{~mm}$ diameter consisted of $1.2 \mathrm{~g}$ of lyophylized tissue. The content of iron per square centimeter was from 80 to $400 \mu \mathrm{g} / \mathrm{cm}^{2}$ for the samples of liver and from 100 to $8000 \mu \mathrm{g} / \mathrm{cm}^{2}$ for the spleen. The spectra were obtained with the absorber at three temperatures : room temperature, liquid nitrogen, and liquid helium.

- The counting times were between 3 days and 2 weeks depending on the content of iron in the absorber. The total number of counts per channel in the 400 channel analyzer was between $10^{7}$ and $6.5 \times 10^{7}$.

3. Results. - Figure 1 shows the Mössbauer spectrum at room temperature and at $4.2 \mathrm{~K}$ of a typical sample lyophylized horse spleen having an elevated iron content of $17.200 \mu \mathrm{g} / \mathrm{g}$. At room temperature the spectrum consists of an $\mathrm{Fe}^{3+}$ doublet with isomeric shift $\delta=0.32 \pm 0.05 \mathrm{~mm} / \mathrm{s}$ relative to iron metal and a quadrupole splitting $\Delta=0.72 \pm 0.05 \mathrm{~mm} / \mathrm{s}$. At liquid helium temperature the spectrum consists of a sextuplet of broadened and asymmetrical lines, characteristic of a magnetically ordered material, a distribution of magnetic field, and an isomeric shift :

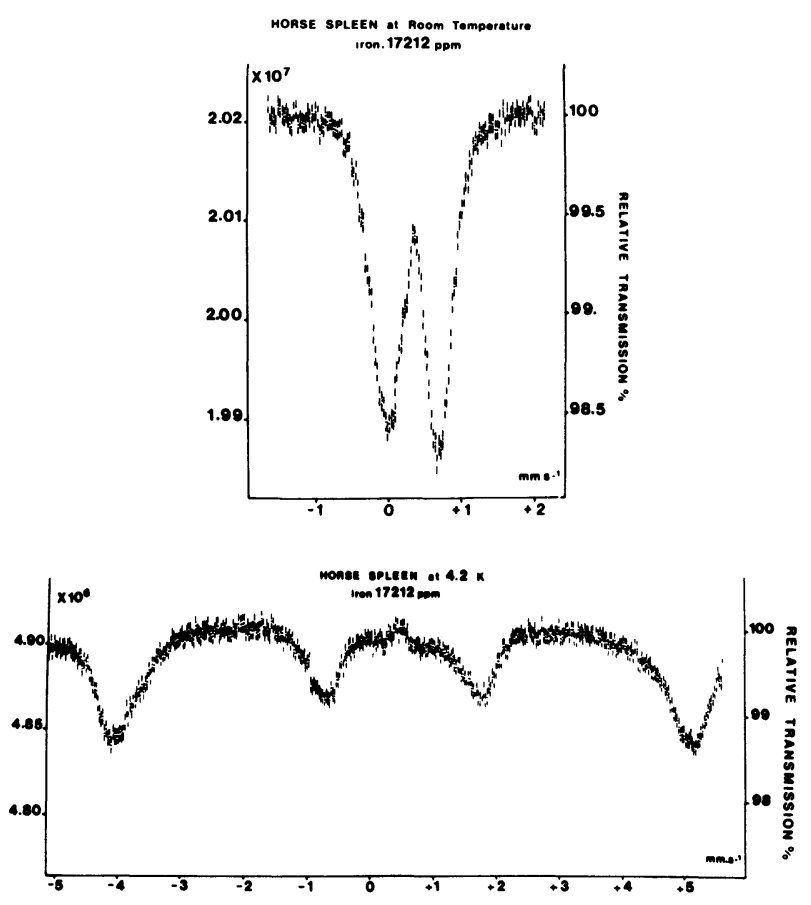

Fig. 1. - Mössbauer spectrum of a lyophylized horse spleen sample. Top) At room temperature. Bottom) At $4.2 \mathrm{~K}$. 
$\delta=0.51 \pm 0.05 \mathrm{~mm} / \mathrm{s}$. This result is completely in agreement with the literature on Mössbauer parameters of ferritin and hemosiderin [5-10]. The characteristic increase of the isomer shift at low temperatures is observed. Between the two inner lines of the spectrum at $4.2 \mathrm{~K}$ an additional component can be seen, which we ascribe to the presence of traces of iron in the beryllium windows of the cryostat.

The results obtained are significantly different from those obtained with lyophylized hepatic tissue. In effect, at liquid helium temperature, the spectrum obtained shows, in addition to the sextuplet, an important doublet. Figure 2 shows typical results for a sample of horse liver, for which the content of iron of $837 \mu \mathrm{g} / \mathrm{g}$ is the highest we have encountered in this organ. The upper part of figure 2 corresponds to the directly recorded spectrum at $4.2 \mathrm{~K}$. Taking into account the low iron content of the sample, this spectrum results from the superposition of the spectrum of the sample itself and that due to traces of iron contained in the beryllium windows of the cryostat. The spectrum of the latter is shown in the middle part of the figure. Finally, the spectrum in the lower part, obtained from the difference of the two preceding ones, corresponds to the spectrum of the sample itself. The latter shows the sextuplet corresponding
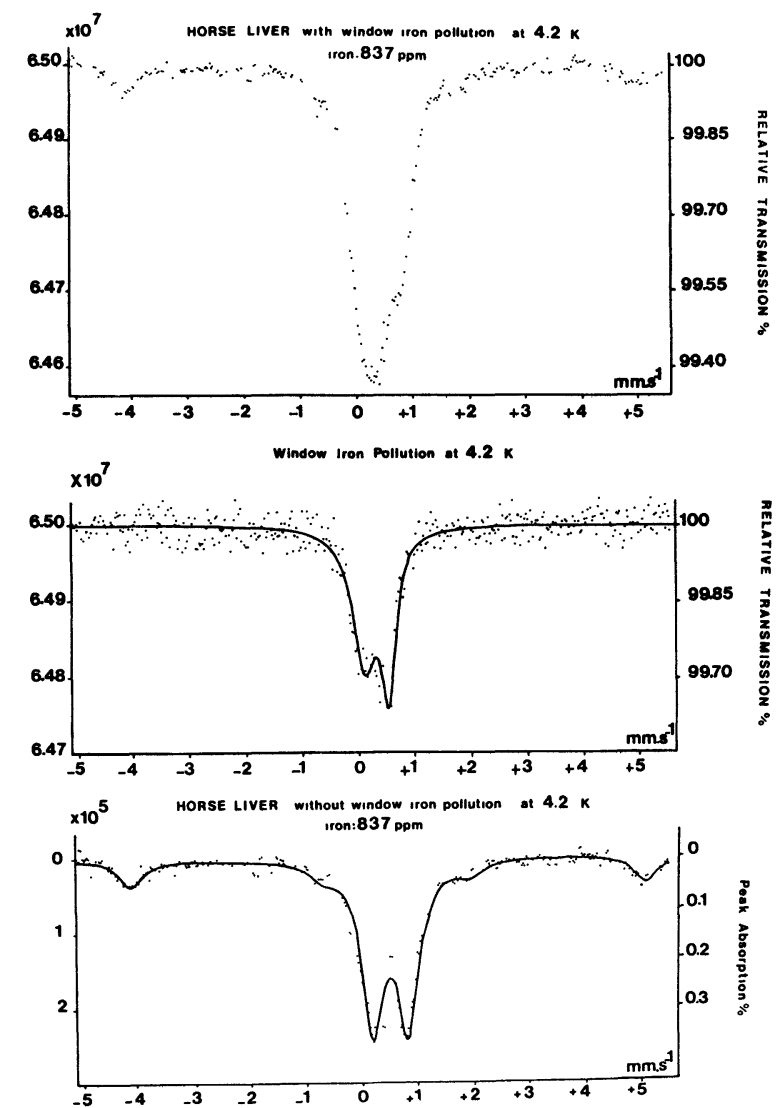

Fig. 2. - Mössbauer spectrum of a lyophylized horse liver sample at $4.2 \mathrm{~K}$. Top) Sample spectrum directly recorded. Middle) Spectrum of the cryostat windows iron traces. Bottom) Difference between the two previous spectra corresponding to the only lyophylized horse liver sample. to ferritin observed in the spleen, plus a doublet $\mathrm{Fe}^{3+}$ with an isomeric shift $\delta=0.50 \pm 0.05 \mathrm{~mm} / \mathrm{s}$ and a quadrupole splitting $\Delta=0.63 \pm 0.05 \mathrm{~mm} / \mathrm{s}$. Within the limits of precision of the measurement, the area under this doublet corresponds to $65 \%$ of the total area under the spectrum. Figure 3 shows the spectrum of the same sample obtained at room temperature. It corresponds to an $\mathrm{Fe}^{3+}$ doublet with isomeric shift $\delta=0.35 \pm 0.05 \mathrm{~mm} / \mathrm{s}$ and a quadrupole splitting $\Delta=0.63 \pm 0.05 \mathrm{~mm} / \mathrm{s}$.

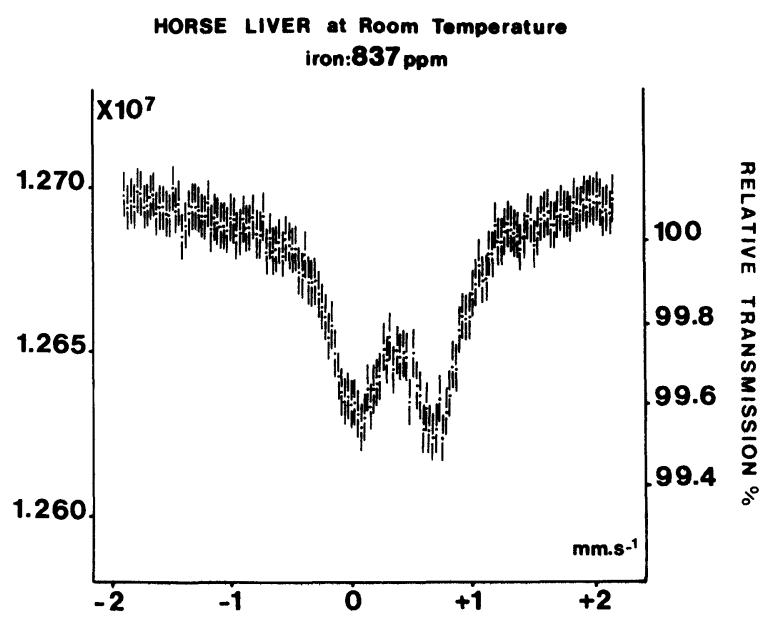

Fig. 3. - Mössbauer spectrum of lyophylized horse liver sample at room temperature.

4. Discussion. - Niitsu and Listowsky, utilizing density gradient centrifugation [12, 13], estimated that the dominant component of ferritin extracted from horse spleen and rat liver contained approximately 2000 atoms of iron per molecule of protein. For such a number of atoms the theory of superparamagnetism shows that the Mössbauer spectrum at $4.2 \mathrm{~K}$ should consist essentially of a sextuplet. This is indeed found in the lyophylized samples of horse spleen. Since we have not been able to study lyophylized samples of rat liver, it is not possible to state whether the corresponding Mössbauer spectra would show a $\mathrm{Fe}^{3+}$ doublet in addition to the ferritin sextuplet. However we are able to demonstrate the appearance of such a doublet in the Mössbauer spec. tra at $4.2 \mathrm{~K}$ in lyophylized sample of horse, beef and calf liver. How can we explain this result ?

Three hypothesis can be advanced. - 1) Lyophylization profoundly perturbs the ferritin molecules, to such an extent as to destroy the magnetic ordering, even at low temperatures. This hypothesis is hardly consistent with the usual view that lyophylization does not seriously disturb the molecules.

2) The dimensions of the iron core in some fraction of the ferritin molecules in horse, beef and calf hepatic tissues are so small that no magnetic order appears at $4.2 \mathrm{~K}$. A rough calculation, based on the 
theory of superparamagnetism, shows that the number of atoms of iron per molecule of ferritin should then be of the order of 300. It remains to be explained why, in the three types of animal studied, this number should be much smaller than in the case of the ferritin in rat liver.

3) Bauminger et al. [14] in the bacterium Escherichia Coli, Dickson and Rottem [15] in Proteus Mirabilis, have discovered a protein of storage iron for which they have not been able to demonstrate a magnetic transition down to temperature below $4.2 \mathrm{~K}$. The existence of an iron reserve protein of this type, different from ferritin, in hepatic tissues of horse, beef and calf would explain our results. This would be completely unexpected. Only a very precise study of the variation of Mössbauer parameters as a function of temperature might serve to confirm or disprove such an hypothesis.

\section{References}

[1] Underwood, E. J., Trace Elements in Human and Animal Nutrition, 2d Edition (Academic Press, New York and London), 1962.

[2] ZUYDERHOUDT, F. M. J. et al., A method for measurement of liver iron fractions in needle biopsy specimens and some results in acute liver disease, Clin. Chim. Acta 86 (1978) 313.

[3] Harrison, P. M. et al., Ferritin and Haemosiderin : Structure and Function, in Iron in Biochemistry and Medicine edited by $\mathrm{A}$. Jacobs and M. Worwood (Academic Press, London and New York), 1974.

[4] Drysdale, J. W. and Ramsay, W. N., The separation of Ferritin and Hemosiderin for studies in the Metabolism of Iron, Biochem. J. 95 (1965) 282.

[5] Blaise, A. et al., Observation par mesures magnétiques et effet Mössbauer d'un antiferromagnétisme de grains fins dans la ferritine, C.R. Hebd. Séan. Acad. Sci. Paris 261 Groupe 5 (1965) 2310.

[6] BoAs, J. F. and Window, B., Mössbauer effect in ferritin, Aust. J. Phys. 19 (1966) 573.

[7] FischiaCH, F. A. et al., On the structure of Hemosiderin and its relationship to ferritin, J. Ultrastructure Research 37 (1971) 495.
[8] Webb, J. and Gray, H., Spectral Studies of the ferritin core and related Iron (III) polymers, Biochem. Biophys. Acta 351 (1974) 224.

[9] Williams, J. M. et al., A Mössbauer determination of the iron core particle size distribution in ferritin, Phys. Med. Biol. 23 (1978) 835.

[10] BAUMingeR, E. R. et al., Quantitative studies of ferritin-like iron in erythrocytes of thalassemia, sickle-cell anemia, and hemoglobin Hammersmith with Mössbauer Spectroscopy, Proc. Natl. Acad. Sci. U.S.A. 76 (1979) 939.

[11] La FleUR, P. D., Biological Matrix Standard reference materials for trace element determinations, J. Radioanal. Chem. 19 (1974) 227.

[12] Nitsu, Y. and Listowsky, I., The distribution of Iron in Ferritin, Arch. Biochem. Biophys. 158 (1973) 276.

[13] NiITsu, Y. and ListowskY, I., Mechanisms for the formation of ferritin oligomers, Biochemistry 12 (1973) 4690.

[14] Bauminger, E. R. et al., Observation of Iron-storage Protein in Escherichia Coli by Mössbauer Spectroscopy, $J$. Physique Colloq. 40 (1979) C2-523.

[15] Dickson, D. P. E. and Rortem, S., Mössbauer Spectroscopy Studies of Iron in Proteus Mirabilis, Eur. J. Biochem. 101 (1979) 291. 